\title{
The Use of the Balanced Scorecard as a Strategic Tool in Public Institutions: A Systematic Review
}

\author{
Juliana Verçosa de Freitas, Marcelo Albuquerque de Oliveira, Gabriela de Mattos Veroneze, \\ and Marcelo Silva Pereira
}

\section{ABSTRACT}

\begin{abstract}
Strategic Planning is one of the management tools most used by institutions that seeks to translate the organization's strategy, define its strategic objectives, identify the main existing bottlenecks and anticipate changes. The indicators are allies of planning and fundamental to the control of processes, because they make it possible to monitor goals, correct problems and propose alternatives for solving possible problems. Therefore, this research consists of verifying the actions outlined in strategic planning in the public sector, using the balanced scorecard tool. For that, a systematic literature review was used as the methodological procedure as the main theme the use of the BSC as a strategic management tool in the public sector. Around 2.003 articles relevant to the proposed theme were identified, selected from 20152020, of which 11 deal directly with the use of the BSC. As a result, the survey found the concern that public organizations have been demonstrating in perfecting their strategic plans by adapting the BSC to the reality of the public sector so that they provide better services to society.
\end{abstract}

Keywords: Strategic planning, Balanced scorecard, Public sector, Methodology.

\section{INTRODUCTION}

One of the main objectives of an organization, whether in the public or private sphere, is the search for continuous improvements in organizational performance, due to the importance of efficiently using the resources available in the execution of the institution's activities. In this scenario marked essentially by the lack of financial resources, public sector organizations have been increasingly pressured to improve their performance, be it in the provision of services to society, or in the transparency of their results [1].

In this context, it is essential to define strategies that define the long-term objectives and goals of the organization, as well as the outline of its actions. Thus, strategy can be defined as a set of decisions by the organization's top management that leads to the development of internal actions, policies, and guidelines, which aim to improve the institution's relationship with its external environment, orienting it towards the market [2]-[4].

For this to happen, it is necessary for the organization to systematize what will be accomplished through strategic planning. Thus, the EP can be defined as an administrative
Submitted : June 11, 2021

Published : July 03, 2021

ISSN: $2507-1076$

DOI: $10.24018 /$ ejbmr.2021.6.4.924

Juliana Verçosa de Freitas*

Technical-Administrative in Education, Master's student in Production Engineering, Federal University of Amazonas, Brazil.

(e-mail: julianavercosa ${ }^{@}$ ufam.edu.br) Marcelo Albuquerque de Oliveira Professor, PhD, Master's Program in Production Engineering, Federal University of Amazonas, Brazil.

(e-mail: marcelooliveira@ ufam.edu.br) Gabriela de Mattos Veroneze

Professor, PhD, Master's Program in Production Engineering, Federal University of Amazonas, Brazil.

(e-mail: gveroneze ${ }^{\circledR}$ ufam.edu.br)

Marcelo Silva Pereira

Professor, $\mathrm{PhD}$, Integration System Department, Eldorado Research Institute, Brazil.

(e-mail: marcelo.pereira@ ${ }^{@}$ eldorado.org.br)

*Corresponding Author tool that, through the analysis of the internal and external environment, becomes aware of its opportunities and threats, its strengths, and weaknesses, indicating a direction to be followed for the organization to reach its objectives [5], [6].

However, due to the complexity involved in the public environment, organizations working in this sphere have difficulties in the elaboration, execution, and monitoring of their strategies, requiring adaptations in the methodologies practiced in the private sector who traditionally used financial measures as an organizational performance parameter, not covering indicators that measure non-financial parameters such as quality, internal processes, human resources, customers [7]. In this perspective, the Balanced Scorecard emerges as a tool that involves both financial and nonfinancial indicators [8], [9].

The balanced scorecard can be defined as a performance measurement methodology, it was created by [10], and originated from research carried out by these researchers in several private institutions. They propose the use of financial metrics, which present the results of actions already taken, and operational metrics, which are drivers for future financial performance. 
As it originates in the private sector, it is necessary to make adaptations in order to provide such applicability in the public sector, one of the main changes being the inversion of the financial perspective that becomes the foundation of the other perspectives of the BSC. Among some benefits of using the $\mathrm{BSC}$ in public institutions, the authors mention integration of budgetary and non-budgetary actions, alignment of organizational strategy with strategic and budget planning, modernization of public management and budgetary control [11], [12].

This research has as general objective to carry out a systematic literature review on the use of the Balanced Scorecard methodology as a strategic tool in public institutions.

The present work will have a brief theoretical reference referring to strategic planning and the Balanced Scorecard methodology, the methods that are intended to be used to obtain the results and, finally, to present the main contributions that were raised in the elaboration of the research related to the proposed theme.

\section{LITERATURE REVIEW}

\section{A. Strategic Planning}

In contemporary society, organizations are exposed to constant changes suffering direct influences from the environment in which they operate. Faced with this scenario of uncertainties, having techniques that assist in the management process is essential. In this sense, strategic planning appears as a tool that seeks to enable the maintenance of organizations in order to respond to the wishes of the environment [13], [14].

Strategic planning is a tool that allows the organization to analyze its internal and external environment, systematizes its mission, vision, values, objectives, and strategies, thus creating basic elements for a good performance [15], [16].

In this perspective, the EP is considered an instrument that guides the organization in the short, medium, and long term [17], where it seeks to identify internal and external threats to the organization, in order to mitigate its obstacles and maximize its opportunities directing their efforts towards the fulfillment of organizational objectives. In this sense, actions pertinent to the applied methodology, to the conception and organization of planning must be aligned with the specificities of the organization, as they need to abide by and incorporate existing decision-making methods and construction models [18], [19].

Following this same line of reasoning, strategic planning drives compliance with strategic actions that cover all areas of the organization, integrating people, perfecting processes, and optimizing resources [20], [21].

Since the 1980s, strategic management has become essential for the public sector, being practiced in several countries and at different levels of government. The use of strategic management in the public sphere was boosted due to the turbulence and transformations in the business environment, caused in the 1970s, where the use of traditional planning became obsolete in the face of the new demands of the market [22]-[23].

\section{B. Balance Scorecard}

The BSC, also known as the Balanced Scorecard, is translated as a company strategy that encompasses the vision, mission, objectives, and related success factors at all levels and in all areas. A methodology translates an organization's strategic objectives into a set of performance indicators [8], [10], [24], [25].

The BSC, or balanced performance indicators, is an advanced management methodology that goes beyond the traditional measurement of results provided by financial or accounting reports, integrating financial and non-financial indicators, representing internal processes, customercompany relations, and the ability to learn and growth [26].

In this sense, the BSC is composed of four perspectives, which are analyzed through the strategic, seeking to generate value: the financial, the customer, the internal business processes and the learning and growth. The financial perspective seeks the strategy of growth, profitability, and risk from the perspective of the shareholder. The customer's perspective seeks a strategy that creates value and differentiation, from the customer's perspective. The perspective of internal business processes focuses on strategies that create satisfaction for shareholders and customers, analyzing various business processes. And the perspective of learning and growth, has as analysis the development of a climate conducive to organizational change, growth, and innovation [27]-[29].

Perspectives are integrated by acting in a cause-and-effect way, that is, the effect caused in one perspective may be a consequence of the result of another. The perspective of learning and growth is the foundation of the organization, as it contributes to continuous improvement through the aggregation of knowledge from the perspective of internal processes, which consequently contributes to the perspective of customer satisfaction and cooperates with the financial perspective in achieving the pre-established objectives. Such perspectives used by the BSC contribute to the organization's internal communication, providing information that serves as a basis for decision-making by top management [30]-[32]. These perspectives are shown on Fig. 1.

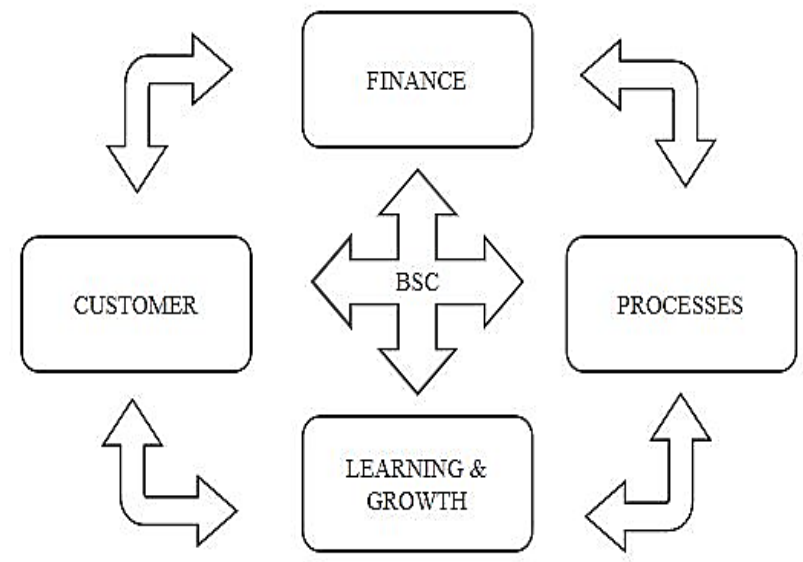

Fig. 1. Balanced Scorecard perspectives.

Following this bias, the BSC is considered an instrument that translates the organization's strategy into short- and longterm objectives, grouping a balanced range of performance indicators in four perspectives, offering managers the view, 
and understanding of the organization from various perspectives at the same time, seeking to achieve the objectives aligned with the organization's strategy [33]-[35].

\section{Methodology}

\section{A. Research Goal}

Systematic reviews should have clear and objective questions, using systematic procedures in order to identify, select and qualitatively analyze relevant research. In this sense, it was decided to use the PRISMA method, which consists of a checklist with 27 items and a flowchart of four steps, with the objective of helping the authors to improve the quality and critical evaluation of its systematic reviews and meta analyzes [36]. The main objective of the research is to identify and evaluate the use of the balanced scorecard methodology as a strategic tool in public institutions.

\section{B. Research Strategy}

The strategy used involved searching for studies on the CAPES Portal (Coordination and Improvement of Higher Education Personnel/Ministry of Education and Culture), through CAFE (Federated Academic Community) access. The consulted journals have their articles available for online consultation, thus facilitating data collection, in addition to concentrating a wide range of different databases. During the systematic review, which took place between January and April 2021, the main keywords related to the guiding question of the research were crossed, resulting in the expression: "balanced scorecard" AND "public sector" AND "strategic planning" AND "methodology", which were used in the search field for subjects in that database. The descriptors were written in the English language as a way to expand the search potential of publications.

\section{Eligibility Criteria}

Only research with the following aspects was included: i) only peer-reviewed scientific articles, since book chapters, case studies and other text formats do not go through the expert evaluation process, as occurs with scientific articles; ii) articles available in full text; iii) articles published in the last 05 (five) years (2015-2020), with the objective of evaluating more current works according to the proposed theme, and iv) works inserted in the topics "balanced scorecard", "public sector", "strategic planning", "management" and "strategic management", seeking to align the identified articles with the central objective of the research.

\section{Sample and Data Collection}

The eligible scientific articles went through a screening process (titles and abstracts). First, the titles of the studies found were read and, later, articles that were not related to the guiding question of the research were excluded. After this phase, the abstracts of the articles selected in the previous phase were read and exclusion of those that also did not fit the theme of the proposed study. Finally, the selected articles were read in full, and these were included in the qualitative analysis of the study. The articles selected in the last step were downloaded through the Google Chrome browser and added to the Mendeley Desktop software to identify possible duplications and, subsequently, to parameterize the selected works.

\section{E. Data Analysis}

At the end of the stages, the main information contained in the included (selected) articles was extracted. The information was analyzed in detail, observing the following points: article title, author / year, sample / location, objective of the study and main results.

\section{FINDINGS AND DISCUSSIONS}

With the completion of the searches and crossing of the keywords, 2,003 articles were found. In the selection stage, the inclusion and exclusion criteria were considered, resulting in 227 scientific articles selected for the later stage. Following this bias, in the eligibility stage, the qualities of the selected productions were verified through the reading and analysis of the titles and abstracts of the articles, with 181 studies excluded by the title and 31 works by the abstract and 04 articles excluded by duplication. The most recurrent reasons for exclusion at this stage were studies applied in institutions that do not fall within the public sphere and studies that used other strategic tools and not the BSC. After all the selection and eligibility process, 11 articles were included in this systematic review study.

The entire process is represented through the flowchart of the Prisma model, as shown in Fig. 2.

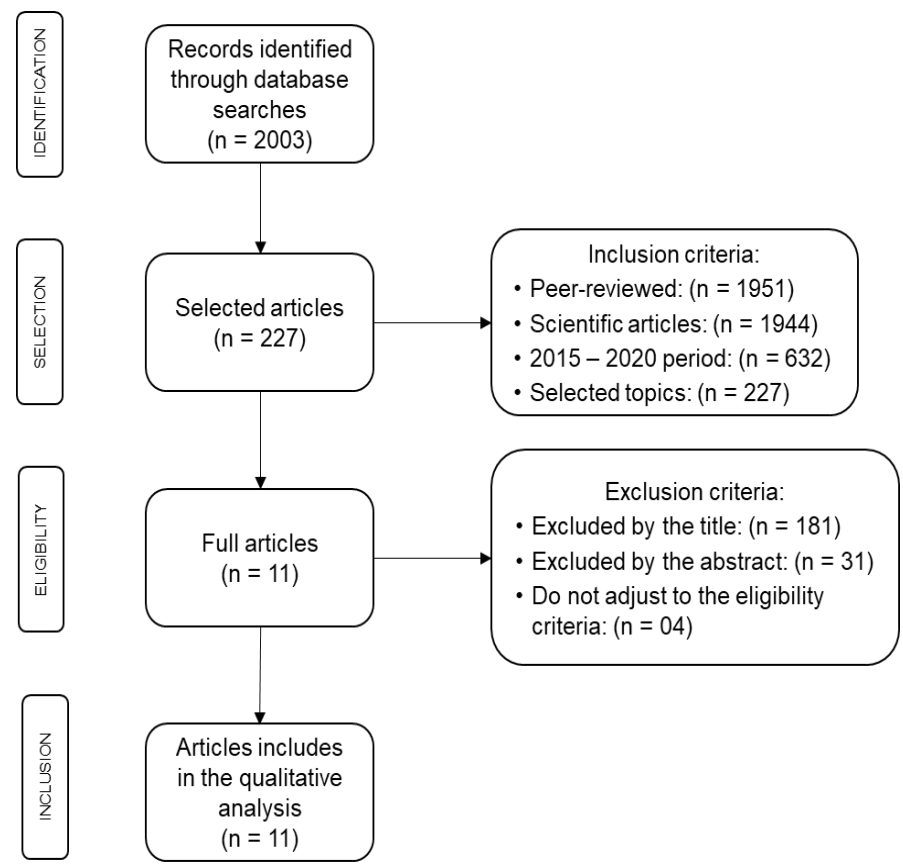

Fig. 2. Prisma model steps.

The main objective of the research was to identify and qualitatively analyze, through a systematic review, the use of the balanced scorecard as a strategic tool in the scope of the public service. Given the above, 2,003 studies were identified, with only 11 articles selected for this work because they are within the scope of the research. As shown in Table I, studies were selected, considering the titles of scientific articles, authors/year of publication, place where the research was carried out and main results found. 
TABLE I: ARTICLES INCLUDED IN THE QUALITATIVE ANALYSIS OF THE SYSTEMATIC REVIEW

\begin{tabular}{|c|c|c|c|c|}
\hline Article name & Author/Year & Local & Study Objective & Main Results \\
\hline $\begin{array}{l}\text { Proposing a basic } \\
\text { methodology for } \\
\text { developing balanced } \\
\text { scorecard by system } \\
\text { dynamics }\end{array}$ & $\begin{array}{l}\text { Espejo, } \\
\text { Khakbaz, S. B., \& } \\
\text { Hajiheydari, N. } \\
(2015)[37]\end{array}$ & $\begin{array}{l}\text { Mashhad Urban Train } \\
\text { (Iranian public } \\
\text { transport company). }\end{array}$ & $\begin{array}{l}\text { Development and application of } \\
\text { the DBSC methodology } \\
\text { developed from the concepts of } \\
\text { the BSC methodology and the } \\
\text { principles of system dynamics. }\end{array}$ & $\begin{array}{l}\text { Creation of a methodology (DBSC) conceived } \\
\text { from the limitations of the BSC, resulting in a } \\
\text { tool with a dynamic strategic management } \\
\text { system, which can be used for several } \\
\text { applications, in addition to developing BSC's. }\end{array}$ \\
\hline $\begin{array}{l}\text { Critical success } \\
\text { factors in the } \\
\text { implementation } \\
\text { process of the } \\
\text { balanced scorecard: } \\
\text { a case study in } \\
\text { federal institutions } \\
\text { of higher education }\end{array}$ & $\begin{array}{l}\text { Cunha, M. R., \& } \\
\text { Kratz, L. (2016) } \\
{[26]}\end{array}$ & $\begin{array}{l}\text { Brazilian Higher } \\
\text { Education Institution }\end{array}$ & $\begin{array}{l}\text { The analysis of the critical } \\
\text { success factors in the } \\
\text { implementation of the Balanced } \\
\text { Scorecard in a Federal } \\
\text { Institution of Higher Education. }\end{array}$ & $\begin{array}{l}\text { Identification of the main problems related to the } \\
\text { implementation of the BSC (Human resources - } \\
34 \% \text { ), identification of the main factors that } \\
\text { contribute to the implementation of the BSC } \\
\text { (Commitment of top management }-47.83 \% \text { ) and } \\
\text { identification of the main barriers for the } \\
\text { implementation of the BSC happen effectively } \\
\text { (Human barrier - } 52.17 \% \text { ). It appears that the } \\
\text { human factor is the main bottleneck in the } \\
\text { implementation of BSC in the investigated } \\
\text { institution. }\end{array}$ \\
\hline
\end{tabular}

Objectives priority Rahimnia, F., \& Ferdowsi University of Develop a BSC-based strategic in university strategy Kargozar, N. Mashhad, capital of the planning model for Ferdowsi map for resource (2016) [38] Iranian province of University of Mashhad (FUM). allocation
Razavi Khorasan.
Greater attention to the perspective of learning and growth, encouraging the education and improvement of its employees, prioritizing the application of an effective management system, improving internal processes, restructuring the organization and establishing an informationbased management system.

It aimed to develop a conceptual basis for the implementation of the BSC at the sectoral and organizational levels. Although the study offers insights into the role of the ideological context in facilitating the constitution of a new trans organizational role for the BSC, it also highlights the extent to which the actors' ambitions to use the BSC in this way have been realized.

\begin{tabular}{|c|c|c|c|c|}
\hline $\begin{array}{l}\text { Implementing the } \\
\text { balanced scorecard } \\
\text { in a local } \\
\text { government } \\
\text { organization } \\
\begin{array}{lr}\text { Evidence } \\
\text { Greece }\end{array}\end{array}$ & $\begin{array}{l}\text { Dimitropoulos, P., } \\
\text { Kosmas, I., \& } \\
\text { Douvis, I. (2017) } \\
{[40]}\end{array}$ & $\begin{array}{l}\text { Municipal } \\
\text { organization of } \\
\text { culture, sport and } \\
\text { environment in the city } \\
\text { of Papagos-Holargos / } \\
\text { Greece. }\end{array}$ & $\begin{array}{l}\text { Examine the issue of } \\
\text { performance management in the } \\
\text { public sector and, specifically, } \\
\text { the implementation of the } \\
\text { balanced scorecard (BSC) } \\
\text { methodology in a public } \\
\text { (municipal) sports organization } \\
\text { in Greece. }\end{array}$ & $\begin{array}{l}\text { It was found that DOPAP, using the BSC, } \\
\text { managed to sustain expenses within budget } \\
\text { constraints and increase its revenues for fiscal } \\
\text { year } 2012,2013 \text { and } 2014 \text {, and at the same time, } \\
\text { achieve high levels of citizen satisfaction with } \\
\text { the sports services and improvement of internal } \\
\text { operations. }\end{array}$ \\
\hline $\begin{array}{l}\text { Factor analysis for } \\
\text { balanced scorecard } \\
\text { as measuring } \\
\text { competitive } \\
\text { advantage of } \\
\text { infrastructure assets } \\
\text { of owned state ports } \\
\text { in Indonesia }\end{array}$ & $\begin{array}{l}\text { Hamid, N. (2018) } \\
\text { [41] }\end{array}$ & $\begin{array}{l}\text { Pelindo IV (Persero) } \\
\text { branch in the city of } \\
\text { Makassar, a port } \\
\text { agency of the } \\
\text { Indonesian } \\
\text { government. }\end{array}$ & $\begin{array}{l}\text { Investigate factor analysis for } \\
\text { BSC as a measure of } \\
\text { competitive advantage of } \\
\text { infrastructure assets of state- } \\
\text { owned ports in Indonesia. }\end{array}$ & $\begin{array}{l}\text { The use of the BSC improved the execution of } \\
\text { the strategic management processes, } \\
\text { clarification of the strategy, communication, } \\
\text { organizational alignment and monitoring of the } \\
\text { objectives and strategic learning. The knowledge } \\
\text { accumulated in the BSC execution process } \\
\text { supports the process of reviewing future } \\
\text { strategies and emerging strategies. However, the } \\
\text { research found that the application of the BSC } \\
\text { alone does not guarantee results, the form of } \\
\text { implementation of the BSC is crucial for the } \\
\text { organization to obtain benefits. }\end{array}$ \\
\hline $\begin{array}{l}\text { Developing a } \\
\text { performance } \\
\text { management model } \\
\text { for the } \\
\text { implementation of } \\
\text { TQM practices in } \\
\text { public education } \\
\text { centers }\end{array}$ & $\begin{array}{l}\text { Mateos-Ronco, } \\
\text { A., \& Hernández } \\
\text { Mezquida, J. M. } \\
\text { (2018) [42] }\end{array}$ & $\begin{array}{lr}\text { Public } & \text { Vocational } \\
\text { Training } & \text { Centers } \\
\text { (PVTCs), Spain. }\end{array}$ & $\begin{array}{l}\text { Development of a BSC for non- } \\
\text { university public teaching } \\
\text { centers (PVTC), using the total } \\
\text { quality management model } \\
\text { (TQM). }\end{array}$ & $\begin{array}{l}\text { It was found that the BSC methodology should } \\
\text { be used as a guide for the implementation and } \\
\text { transmission of the strategy, serving as a basis } \\
\text { for communicating and understanding what } \\
\text { really creates value, thus using it, in the } \\
\text { development of strategies and schemes to } \\
\text { improve organizational performance of these } \\
\text { non-university public education centers. }\end{array}$ \\
\hline $\begin{array}{l}\text { Operationalizing } \\
\text { performance } \\
\text { management in local } \\
\text { government: The } \\
\text { use of the balanced } \\
\text { scorecard }\end{array}$ & $\begin{array}{l}\text { Ndevu, Z. J., \& } \\
\text { Muller, K. (2018) } \\
\text { [43] }\end{array}$ & $\begin{array}{l}\text { Joe Gqabi District } \\
\text { Municipality (JGDM) } \\
\text { in the Eastern Cape } \\
\text { Province, South } \\
\text { Africa. }\end{array}$ & $\begin{array}{l}\text { Examine how the balanced } \\
\text { scorecard (BSC) can be used to } \\
\text { improve performance in the } \\
\text { context of local government } \\
\text { and help to eradicate the } \\
\text { current challenges of a lack of } \\
\text { quality services, poverty and } \\
\text { infrastructure development. }\end{array}$ & $\begin{array}{l}\text { The study points out that the use of BSC can be } \\
\text { used as an important strategic management tool } \\
\text { by local governments, allowing management to } \\
\text { evaluate their financial, internal, learning } \\
\text { processes and the services provided to their } \\
\text { customers. Stresses that implementation must } \\
\text { be driven from the top down to operational } \\
\text { levels and that leadership, change orientation } \\
\text { and collaborative decision-making are essential } \\
\text { for the implementation of a BSC in local } \\
\text { government. }\end{array}$ \\
\hline
\end{tabular}

Examine the adoption of balanced scorecard (BSC) by public sector health organization. adoption: an

Ethiopian case study
Obo, D. (ALERT), Etíópia.

\begin{tabular}{llll}
\hline $\begin{array}{l}\text { Public-sector } \\
\text { reforms and }\end{array}$ & Bobe, B. J., & All African Leprosy \\
balanced scorecard & Obo, D. D. (2017) & Research and Training \\
adoption: ALERT), Etiópia. & an & [39] &
\end{tabular}

Examine the adoption of the
balanced scorecard (BSC) by a
public sector health
organization.


TABLE I (CONT.): ARTICLES INCLUDED IN THE QUALITATIVE ANALYSIS OF THE SYSTEMATIC REVIEW

\begin{tabular}{|c|c|c|c|c|}
\hline Article name & Author/Year & Local & Study Objective & Main Results \\
\hline $\begin{array}{lr}\text { A } & \text { balanced } \\
\text { scorecard } & \text { for } \\
\text { assessing a strategic } \\
\text { plan in a clinical } \\
\text { laboratory }\end{array}$ & $\begin{array}{l}\text { Alvarez, L., Soler, } \\
\text { A., Guiñón, L., \& } \\
\text { Mira, A. (2019) } \\
{[44]}\end{array}$ & $\begin{array}{l}\text { Public } \quad \text { Clinical } \\
\text { Analysis Laboratory, } \\
\text { Catalonia / Spain. }\end{array}$ & $\begin{array}{l}\text { Development of a BSC for a } \\
\text { clinical laboratory in the public } \\
\text { health sector in Catalonia / } \\
\text { Spain. }\end{array}$ & $\begin{array}{l}\text { The BSC proved to be a useful methodology in } \\
\text { validating effectiveness both in the } \\
\text { implementation of the defined initiatives, as } \\
\text { well as in the development of the organizational } \\
\text { strategy. In addition, its applicability showed } \\
\text { how the laboratory has the capacity to generate } \\
\text { self-financing that allows it to invest in actions } \\
\text { geared towards better services provided to its } \\
\text { customers. The annual results of the proposed } \\
\text { indicators allowed the identification of the } \\
\text { perspectives that should have their efforts } \\
\text { prioritized. }\end{array}$ \\
\hline
\end{tabular}

\begin{tabular}{|c|c|}
\hline Strategic & de Oliveira, P. H., \\
\hline Management & Paschoalotto, M. \\
\hline Public & A. C., de Godoy \\
\hline Administration: & Delmônico, D. V., \\
\hline Balanced Scorecard & de Souza Coelho, \\
\hline Applicability & F., Santos, F. C. \\
\hline Framework & A., \& Escrivão \\
\hline School Management & Filho, E. (2020) \\
\hline
\end{tabular}

[45]

\begin{tabular}{|c|c|}
\hline $\begin{array}{l}\text { Public } \\
\text { Associations, located } \\
\text { in the city of Ribeirão } \\
\text { Preto / SP - Brazil. }\end{array}$ & $\begin{array}{l}\text { in public school ass } \\
\text { São Paulo / Brazil. }\end{array}$ \\
\hline
\end{tabular}

Among the results, the importance of strategic management in public schools through the BSC methodology is highlighted. With the development and application of the BSC, the authors adapted this methodology to the researched organization, redefining the perspectives of the BSC, outlining long-term objectives and goals for the organization. Thus, new instruments are available for strategy projects, which can help to improve the performance of school units, both in the pedagogical and administrative aspects.

\begin{tabular}{|c|c|c|c|c|}
\hline $\begin{array}{l}\text { Designing a human } \\
\text { resource scorecard: } \\
\text { An empirical } \\
\text { stakeholder-based } \\
\text { study with a } \\
\text { company culture } \\
\text { perspective }\end{array}$ & $\begin{array}{l}\text { Boudlaie, H., } \\
\text { Mahdiraji, H. A., } \\
\text { Shamsi, S., Jafari- } \\
\text { Sadeghi, V., \& } \\
\text { Garcia-Pereze, A. } \\
\text { (2020) [46] }\end{array}$ & $\begin{array}{l}\text { HR Units of the Kish / } \\
\text { Iran Free Zone } \\
\text { Organization. }\end{array}$ & $\begin{array}{l}\text { The research aims to identify } \\
\text { the strategic objectives and the } \\
\text { strategic map of the HRM in the } \\
\text { Kish Free Zone Organization } \\
\text { (KFZO), using a balanced } \\
\text { scorecard approach based on } \\
\text { thematic analysis and the } \\
\text { perspective of the company's } \\
\text { culture. }\end{array}$ & $\begin{array}{l}\text { Development of a specific method of qualitative } \\
\text { analysis to identify the strategic objectives of } \\
\text { HR, which can be used by several organizations } \\
\text { in the creation of an HR scorecard, identifying } \\
\text { the basic, organizational and global themes, } \\
\text { mapping the thematic network and creating the } \\
\text { organizational strategic map. be a guide for } \\
\text { determining operational objectives and } \\
\text { implementing the strategy. }\end{array}$ \\
\hline
\end{tabular}

According to [10], the BSC is more than a performance measurement tool, as it encompasses four interconnected processes: strategy planning, feedback and learning, translation of the organization's vision and communication and process alignment. Following this bias, it is noted that 09 studies $(82 \%)$ understand the importance of implementing a methodology capable of translating strategic objectives into results, improving the organization's strategic management, as shown in Fig. 3.

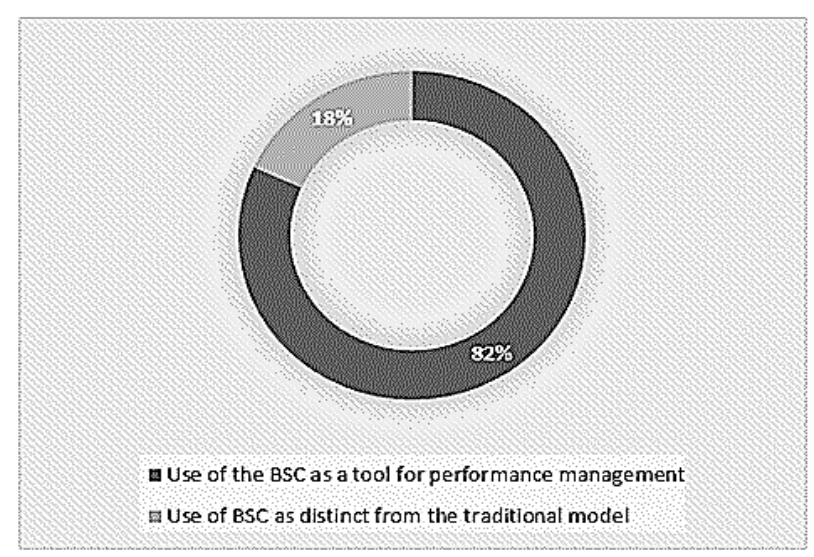

Fig. 3. Applicability of BSC as a management tool.

The largest number of studies are from Iran with 03 publications, followed by Brazil with 02articles and Spain with the same number of publications. Indonesia, Australia, Greece, and South Africa each follow with 01 publication each. Regarding the number of authors, there were a total of 33 researchers involved in the production of the 11 studies in this systematic review.

The studies included in this research showed that the use of the BSC must be adapted according to its demands, needs and specificities that each organization needs. In this perspective, in order to facilitate the understanding and contribution of the articles, they were grouped by theme, but each study has different objectives, methodologies and samples.

In Table 2, the 11 articles were grouped into four themes, which follows: i. Education; ii. Public policy; iii. Public Health System; iv. Transport.

The theme that grouped the largest number of publications (36\%) concerns the applicability of the BSC methodology in the public sphere of education. Studies such as de [45] demonstrated the lack of knowledge of public-school teaching managers regarding strategic planning.

Following this bias, [26] investigated in their study, the critical success factors in the implementation of a BSC in a Federal Educational Institution. The results found by the researchers found that the main barrier in the implementation of a BSC was related to the human factor of the organization.

[42] report in their study the creation of a strategic plan using the BSC and the principles of the Total Quality Management (TQM) theory, for non-university public education centers. The authors report the capacity that the $\mathrm{BSC}$ has in adapting to the philosophy of public management; however, this single factor does not guarantee its success as a strategic tool. Thus, to ensure that the BSC methodology corresponds to the specificities of educational centers, the Delphi method was used, allowing the BSC to be fully aligned with the characteristics of the environment. 
TABLE II: NUMBER OF ARTICLES FOUND BY SUBJECT AND BY AUTHOR

\begin{tabular}{cccc}
\hline \hline Theme & Authors & $\mathrm{N}^{\circ}$ studies & $\%$ \\
\hline Education & {$[26] ;[38] ;[42] ;[45]$} & 4 & $36,36 \%$ \\
$\begin{array}{l}\text { Public } \\
\text { Policy }\end{array}$ & [40]; [43]; [46] & 3 & $27,27 \%$ \\
$\begin{array}{l}\text { Public } \\
\text { Health }\end{array}$ & [39]; [44] & 2 & $18,18 \%$ \\
System & & & \\
Transport & [37]; [41] & 2 & $18,18 \%$ \\
Total & & 11 & $100 \%$ \\
\hline \hline
\end{tabular}

In this same perspective, [38] presented in their study the creation of a strategic map for a public university using the DEMATEL method, which used matrix calculations to create a visual panel that illustrates the interrelationships between the components and separate them into groups of cause and groups of effects.

The researchers found, with the applicability of the tool and the creation of the strategic map, that the most relevant factor is the competence of the university's human capital, an asset that is directly linked to the perspective of learning and growth. [10] corroborate that such perspective is the basis of an organization's strategic plan.

The second largest group of authors dealt with the topic of Public Policies. This group accumulated a total of $27 \%$ of publications. [40] demonstrated the application of the BSC in a municipal sports center and report as the main results that the implementation of the BSC as a strategic tool enabled the government to increase tax revenues in three consecutive years (2012, 2013 and 2014), providing better investments and, consequently, raising the level of services provided to society.

In this bias, [46] used the BSC as an instrument for the identification of strategic objectives and the creation of a strategic map for the management of human resources in the Kish Free Zone / Iran. The researchers reported the importance of a human capital development strategy based on the client and the orientation, confirming the impact generated by the human factor on the organization's culture, and consequently, on its performance.

[43] examined how the BSC can be used to improve performance in the local context of a developing country, assisting in community service delivery, infrastructure development, poverty eradication, among other challenges. As main consequences, the researchers confirmed that the BSC should be a methodology implemented in the long term, developing and implementing strategies instead of being used purely in measurement, they also report that the reports based on the BSC can contribute to the accountability of managers.

Regarding the Public Health System theme, a total of $18 \%$ of publications were found. The researchers [44], verify the effective applicability of the BSC in a clinical health laboratory, reported in their study that the BSC may prove to be a useful tool for managers in order to demonstrate the laboratory's strategy, initiatives to be prioritized aiming at the achievement of the established objectives, they also ratify that the proposed indicators allow to identify which fields should be prioritized.

In contrast, [39] report the main barriers and difficulties in implementing the BSC in a public health organization. The authors found the BSC to be incompatible with management systems linked to that organization, with the political influence as its axis restricting the flexibility in the use of performance evaluation systems, proposed by the BSC methodology.

The inflexible financial management policy was another factor that inhibited the performance that stimulates the potential of using the BSC. However, the researchers found that the implemented BSC was found to be useful, even though it was considerably overhauled to meet the organization's needs.

Finally, there is the theme related to transportation, representing $18 \%$ of the total publications. In this perspective, [37], created a methodology (DBSC) based on the limitations of the BSC traditionally created by [10] being the tool applied in an Iranian public transport company.

The main innovation proposed by the authors was the use of systems dynamics as a methodology for creating BSC's, with less subjective influence from the developer. Following this bias, [41] demonstrates in his study the use of factor analysis for the BSC as a measure of competitive advantage in infrastructure assets in state ports in Indonesia. As a result, the author reports that the main asset that offers gains in competitive advantage is the learning perspective, with human capital as its main intangible asset.

\section{CONCLUSION}

In this systematic review, it was found that $82 \%$ of the studies ratify the importance of public organizations in developing and using strategic tools in their environments.

In addition, it was found that the BSC methodology is a tool that can be adapted and can be formulated according to the needs of each context.

The new demands of society, rapid technological changes and budgetary constraints are some factors that demand efforts in the capacity of public organizations to adapt to this new context and to seek methodologies that assist in the performance management of the institution.

Although this research has made an attempt to identify research that used the BSC as a strategic tool in the public sector, its impacts and contributions, further studies of systematic reviews with a larger sample time are still needed, in order to demonstrate the evolution of practical cases of using this tool in the public service and comparing the BSC with other similar strategic tools.

As limitations, it can be highlighted that this study was limited in analyzing the impacts of only one strategic methodology, the balanced scorecard. The study was also limited to analyzing the impacts on the use of this tool only in the public sector, in view of the specificities that the public sphere demands.

\section{ACKNOWLEDGMENT}

The authors thank the Postgraduate Program in Production Engineering (PPGEP) of the Federal University of Amazonas (UFAM) for their support and structure. This work was carried out with the support of the Amazonas State Research Support Foundation (FAPEAM) under PosGrad Program.

\section{REFERENCES}

[1] Bandeira, Herivânio Torres; Amorim, Tânia Nobre Gonçalves Ferreira Percepção dos servidores públicos sobre planejamento estratégico organizacional: o caso de uma unidade descentralizada do MPF através da implantação do balanced scorecard. REUNIR Revista de 
Administração Contabilidade e Sustentabilidade, v. 10, n. 2, p. 66-77, 2020.

[2] Souza, C. M. L. d. Entre o planejamento estratégico formal e informal: um estudo de caso exploratório sobre a prática de estratégia nas organizações. Revista de Administração Contemporânea 15, p. 855 876, 2011.

[3] da Silva, P. G., de Araújo, A. G., da Silva Damasceno, L. M., \& Serralvo, F. A. O processo da estratégia sob a visão dos decisores. Revista Capital Científico-Eletrônica (RCCe)-ISSN 2177. 4153, 15(3), 42-58, 2017.

[4] Ferreira, João J.; Raposo, Mário L.; Mainardes, Emerson Wagner. Strategy and strategic management concepts: are they recognised by management students?. Economics and Management, 2014.

[5] Albano, Claudio Sonaglio; Garcia, Fabiane Tubino. (2015). O impacto do método e de fatores organizacionais no processo de planejamento estratégico: estudo de caso em uma universidade federal. Parcerias Estratégicas, v. 18, n. 37, p. 151-172, 2015.

[6] Farias, Sandy Wene Ferreira; LIMA, Antonio Raniel Silva. Um estudo bibliográfico sobre o planejamento estratégico em micro e pequenas empresas. Entrepreneurship, v. 4, n. 1, p. 34-41, 2020.

[7] Nahmias, P. S. (2014). A Importância do planejamento para a gestão pública. Revista Científica DR, v. 5, n. 5.

[8] Blonski, Fabiano; PRATES, Rodolfo Coelho; Costa, Mayla; Vizeu, Fábio. O controle gerencial na perspectiva do new public management: o caso da adoção do balanced scorecard na receita federal do brasil. Administração Pública e Gestão Social, 9(1), jan.-mar., 15- 30, 2017.

[9] De Carvalho Filho, M. \& Amorim, T. N. G. F. (2020). Inovação da Gestão Estratégica com a Implantação do Balanced Scorecard. Management Control Review, v. 5, n. 1, p. 19-33.

[10] Kaplan, R. S.; Norton, D. P. The Balanced Scorecard: Measures that Drive Performace. Harvard Business Review 70, no. 1 (JanuaryFebruary): 71-79, 1992.

[11] Felix, Rozelito; FELIX, Patrícia do Prado; TIMÓTEO, Rafael. Balanced Scorecard: adequação para a gestão estratégica nas organizações públicas. Revista do Serviço Público. Brasília 62 (1): 51 74 Jan/Mar 2011.

[12] Santos, Yuri Dantas; Callado, Antônio André Cunha. Balanced scorecard no setor público: uma análise de sua aplicação nos ministérios públicos estaduais. Revista Capital Científico-Eletrônica (RCCe)-ISSN 2177-4153, v. 17, n. 2, p. 86-100, 2019. (13)

[13] Andrade, Herlandí de Souza; LOUREIRO, Geilson. Proposta de um modelo de planejamento estratégico baseado em engenharia de sistemas. Revista Espacios, v. 39, n. 13, p. 10-26, 2018. (14)

[14] Costa, C. C. Seleção de indicadores para a gestão do planejamento estratégico da Polícia Militar do Estado de Sergipe. Revista Boletim do Gerenciamento, v. 20, n. 20, p. 1-13, 2020.

[15] Teixeira, Carlos Alberto Chagas; Dantas, Giane Gomes Teixeira; Barreto, Carla Alessandra. A importância do planejamento estratégico para as pequenas empresas. Revista eletrônica científica da FAESB, v. 1, n. 2, 2018

[16] Schmidt, J. M. Policy, planning, intelligence and foresight in government organizations. Foresight, 17 (5): 489-511, 2015.

[17] Neis, DF, Pereira, MF, \& Maccari, EA. Processo de Planejamento Estratégico e Estrutura Organizacional: Impactos, Confluências e Similaridades. Brazilian Business Review. 14 (5), 479 492, 2017.

[18] Pereira Junior, Errol Fernando Zepka; Schroeder, Eliza Antonini; Dolci, Décio Bittencourt. Limitações digitais, causas e consequências na efetividade do uso do site trello no planejamento estratégico de uma secretaria de educação a distância de uma universidade federal. Revista de Educação a Distância, V. 6, n. 1, 2019.

[19] Bryson, J. M. Strategic planning for public and nonprofit organizations: A guide to strengthening and sustaining organizational achievement. 5. ed. New York: John Wiley \& Sons, 2018.

[20] Lugoboni, L. F., de Brito Alencar, E. A., Zittei, M. V. M., \& Chirotto, A. R. Alinhamento entre Planejamento Estratégico e Sistema de Informação Gerencial: Estudo em Empresas do Terceiro Setor com Atividade Hoteleira. PODIUM Sport, Leisure and Tourism Review, 7(1), 79-105, 2018.

[21] Varela, A. V., Barbosa, M. L. A, \& Farias, M. G. G. Abordagem cognitiva para gestão do planejamento estratégico nas organizações. Perspectiva em Gestão e Conhecimento, 5(2), 49-68, 2015.

[22] Fenner, V. U., Scheid, L. L., Dalcin, D., \& Anes, C. E. R. A transparência como instrumento de acompanhamento do planejamento estratégico público municipal. Práticas de Administração Pública, 3(1), 45-62, 2019.

[23] Johnsen, Åge. Strategic management thinking and practice in the public sector: A strategic planning for all seasons?. Financial Accountability \& Management, v. 31, n. 3, p. 243-268, 2015.

[24] De Oliveira, Jane Maria; Izelli, Reginaldo César. Indicadores de desempenho baseados no balanced scorecard: um modelo adaptado à administração pública. Refas-Revista Fatec Zona Sul, v. 4, n. 2, p. 37 $51,2018$.

[25] Andrade, Alexandre Galvez; Moraes, Yohanna Godinho da Silva; Mangini, Eduardo Roque. $\mathrm{O}$ balanced scorecard aplicado à administração pública municipal: um estudo na prefeitura de ibiúna, Estado de São Paulo. Revista Gestão em Análise, v. 9, n. 1, p. 123-135, 2020.

[26] Cunha, M. R. \& Kratz, L. Fatores críticos de sucesso no processo de implementação do Balanced Scorecard: um estudo de caso nas instituições federais de ensino superior. Revista de Ciências da Administração, 18(46), 96-108, 2016.

[27] Nascimento, J. C. do., Santos, R. e Coelho, J.. Aplicação do Planejamento Estratégico na Superintendência Estadual de Navegação, Portos e Hidrovias - SNPH. XXXVIII Encontro Nacional De Engenharia De Produção. Maceió, Alagoas, Brasil. 2018.

[28] CRISPIM, Ingrid Aparecida Siqueira; ROMEIRO, Vladimir. Balanced Scorecard. Revista Gestão \& Sustentabilidade, v. 1, n. 1, p. 233-249, 2019.

[29] dos Santos Portugal, N., da Silva, S. V., de Paula Souza, A. A., Paiva, L. R., \& de Souza, W. G. A adaptação do balanced scorecard ao sinaes: um estudo de caso em uma instituição de ensino superior privada. Brazilian Journal of Business, 2(4), 3851-3868, 2020.

[30] DA SILVA, Gilson Rodrigues et al. Utilização de indicadores de desempenho à luz das perspectivas do balanced scorecard em cooperativas de créditos. Escritos Contables y de Administración, v. 11, n. 1, p. 24-47, 2020.

[31] Kruger, D. S., Simionato, A., Zanella, C. \& Murilo Petri, S. Balanced Scorecard: Uma Proposta Para A Gestão Estratégica De Uma Cooperativa De Crédito Rural. Brazilian Journal of Management/Revista de Administração da UFSM, 11 (1), 1-18, 2018.

[32] Rahman, S. A., Amran, A., Ahmad, N. H., \& Taghizadeh, S. K Enhancing the wellbeing of base of the pyramid entrepreneurs through business success: the role of private organizations. Social Indicators Research, 127 (1), 195-216, 2016.

[33] Callado, A. A. C., \& Amorim, T. N. G. G. Especificidades das estruturas de Balanced Scorecard: um estudo exploratório a partir do gênero dos gestores. Revista Conhecimento Contábil UERN/UFERSA, 7(2), 01-16, 2018.

[34] Fernandes, A. G., Furtado, R. P. M., \& Ferreira, P. A. Aplicação do balanced scorecard no auxílio à formulação do planejamento estratégico no setor público: o Caso DAE/Ufla. Revista Economia \& Gestão, 16(42), 218-244, 2016.

[35] Araújo, R. H. M. A adoção do BSC para a mensuração do desempenho estratégico governamental: o caso do governo de Pernambuco. Dissertação de Mestrado, Universidade Federal Rural de Pernambuco, Recife, PE, Brasil, 2017.

[36] Galvão, T. F.; Pansani, T. S. A.; Harrad, D. Principais itens para relatar Revisões sistemáticas e Meta-análises: A recomendação PRISMA Epidemiologia e Serviços de Saúde, Brasília, 24(2), 335-342, 2015.

[37] ESPEJO, Raul; Khakbaz, Seyed Behnam; Hajiheydari, Nastaran. Proposing a basic methodology for developing balanced scorecard by system dynamics approach. Kybernetes Journal, V. 44, n. 6/7, p. 10491066, 2015.

[38] Rahimnia, Fariborz; kargozar, Naghmeh. Objectives priority in university strategy map for resource allocation. Benchmarking: An International Journal, Benchmarking, Vol. 23, No. 2, pp. 371-387, 2016.

[39] Bobe, Belete Jember; Mihret, Dessalegn Getie; OBO, Degefe Duressa. Public-sector reforms and balanced scorecard adoption: an Ethiopian case study. Accounting, Auditing \& Accountability Journal, Vol. 30 No. 6, pp. 1230-1256, 2017.

[40] Dimitropoulos, Panagiotis; Kosmas, Ioannis; Douvis, Ioannis. Implementing the balanced scorecard in a local government sport organization. International Journal of Productivity and Performance Management, Vol. 66 No. 3, pp. 362-379, 2017.

[41] Hamid, Nurdjanah. Factor analysis for balanced scorecard as measuring competitive advantage of infrastructure assets of owned state ports in Indonesia: Pelindo IV, Makassar, Indonesia. International Journal of Law and Management, Vol. 60 No. 2, pp. 386-401, 2018.

[42] Mateos-Ronco, Alicia; Hernández Mezquida, José Manuel. Developing a performance management model for the implementation of TQM practices in public education centres. Total Quality Management \& Business Excellence, v. 29, n. 5-6, p. 546-579, 2018.

[43] Ndevu, Zwelinzima J.; Muller, Kobus. Operationalising performance management in local government: The use of the balanced scorecard. SA Journal of Human Resource Management, v. 16, n. 1, p. 1-11, 2018.

[44] Alvarez, Luisa et al. A balanced scorecard for assessing a strategic plan in a clinical laboratory. Biochemia medica, v. 29, n. 2, p. 284-291, 2019. 
[45] DE Oliveira, P. H, Paschoalotto, M. A. C, Delmônico, D. V. G, Coelho, F. S, Santos, F. C. A, Filho. E. E. Strategic Management in Public Administration: A Balanced Scorecard Applicability Framework in School Management. Future Studies Research Journal: Trends and Strategies, v. 12, n. 3, p. 458, 2020.

[46] Boudlaie, Hasan et al. Designing a human resource scorecard: An empirical stakeholder-based study with a company culture perspective. Journal of Entrepreneurship, Management and Innovation, v. 16, n. 4 , p. $113-147,2020$

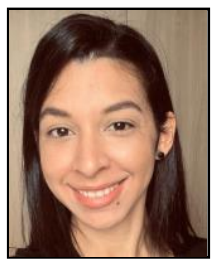

Juliana Verçosa is a student in the master's Program in Production Engineering at Federal University of Amazonas. She is a TechnicalAdministrative in Education currently and serves as Head of Materials at the Federal University of Amazonas.

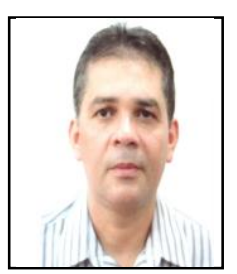

Marcelo Oliveira is an Adjunct Professor of Department of Production Engineering and member of Master Program in Production Engineering, Federal University of Amazonas. He has published several Research Papers related to Engineering area.

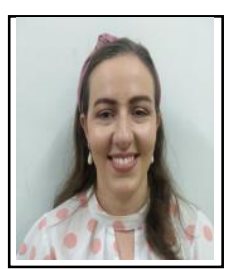

Gabriela Veroneze is an Adjunct Professor, Department of Production Engineering and member of Master Program in Production Engineering, Federal University of Amazonas. She has published several Research Papers related to Engineering area.

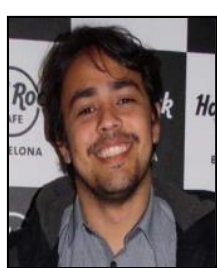

Marcelo Pereira is a Product Management Specialist in Eldorado Research Institute using lean/agile methodologies to develop new systems and manage collaborative teams. 